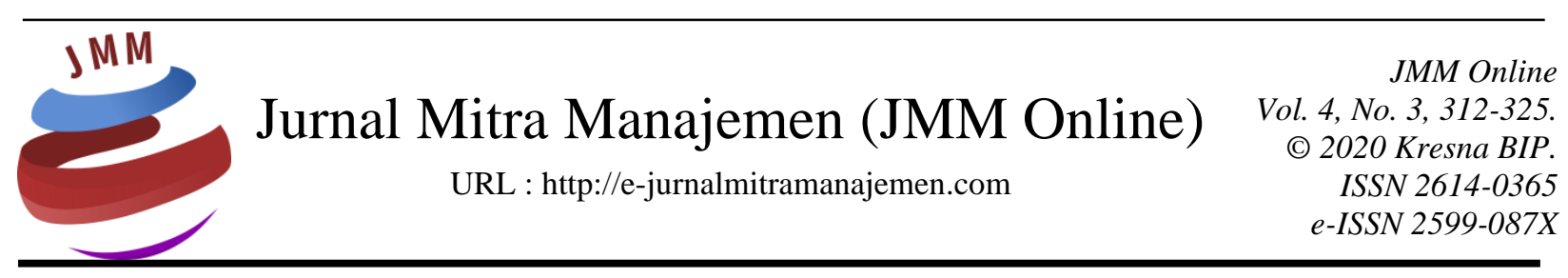

\title{
IMPLEMENTASI DEA DALAM ANALISA EFISIENSI KINERJA \\ DEPNAKERTRANS JAWA BARAT \\ BERDASARKAN TINGKAT PENDIDIKAN
}

\author{
Rosmita ${ }^{1)}$, Ety Nurhayaty ${ }^{2)}$, Dini Setyorini ${ }^{3)}$ \\ Universitas Bina Sarana Informatika
}

INFORMASI ARTIKEL

Dikirim : 16 Januari 2020

Revisi pertama : 26 Maret 2020

Diterima : 27 Maret 2020

Tersedia online : 30 Maret 2020

Kata Kunci : DEA, Kinerja Depnakertrans

Email : rosmita.rmt@bsi.ac.id

\section{ABSTRAK}

Depnakertrans Jawa Barat merupakan Instansi teknis yang melaksanakan sebagian urusan pemerintahan dan pembangunan di bidang ketenagakerjaan dan ketransmigrasian. Salah satu program dari depnakertrans adalah peningkatan kesempatan kerja dengan melakukan berbagai kegiatan.

Tujuan dari penelitian ini adalah untuk mengetahui efesiensi kinerja depnakertrans dalam memberikan kesempatan kerja kepada penduduk Jawa Barat berdasarkan tingkat pendidikan mereka dengan metode Data Enfelopment Analisis (DEA).

Hasil dari penelitian ini menunjukkan bahwa tidak semua tingkat pendidikan dapat dilakukan dengan efesien dalam penempatan kerja oleh depnakertran khusus nya untuk tingkat pendidikan SD ke bawah. 


\section{PENDAHULUAN \\ Latar Belakang}

Peningkatan jumlah penduduk merupakan suatu persoalan pemerintah dalam meningkatkan kwalitas sumberdaya manusia, sehingga siap bersaing ditingkat nasional maupun internasional. Depnakertrans adalah salah satu instansi pemerintah yang mengelola ketenagakerjaan penduduk Indonesia agar pertumbuhan penduduk berimbang dengan kesediaan lapangan kerja sehingga tidak terjadi lonjakan pengangguran. Untuk mengatasi hal ini berbagai kegiatan dan program dilakukan oleh instansi pemerintahan khusus nya depnakertrans.

Keberhasilan dari suatu instansi dipengaruhi oleh beberapa faktor diantaranya kedisiplinan karyawan, skill atau kemampuan karyawan, program kerja dari instansi apakah benar-benar efektif dalam melayani masyarakat, serta faktor masyarakat dan lingkungan nya apakah bisa menerima program dan kebijakan yang diterapkan kepada masyarakat tersebut, semua ini dapat dilihat dari hasil kinerja instansi tersebut apakah efektif dan efesien.

Untuk mengetahui kinerja instansi depnakertrans perlu dilakukan analisis kinerja apakah program dan kegiatan yang dilakukan sudah efesien.

Alat analisis yang digunakan untuk mengetahui kinerja instansi depnakertrans Jawa Barat dalam penempatan atau pengelolaan tenaga kerja berdasarkan tingkat pendidikan adalah dengan DEA (Data Envelopment Analysis). Data Envelopmet (DEA) adalah salah satu instrunen untuk menelaah efesiensi suatu unit manajemen dan membandingkan dengan unit-unit manajemen lain di dalam sampel, yang dalam kegiatan manajemennya melibatkan banyak jenis input (multi-input) dan banyak jenis out put (multi-output). Data Envelopment Analysis (DEA) dapat mengatasi keterbatasan yang ada pada teknik analisis rasio parsial dan regresi berganda dalam mengevaluasi kinerja efisiensi sekumpulan unit manajemen.

Efisiensi relative suatu unit manajemen adalah efisiensi suatu unit manajemen disbanding dengan efisiensi unit manajemen lain dalam sampel yang sedang dibicarakan (sedang diperbandingkan) yang semuanya memiliki jenis input dan output yang sama. Problem utama yang harus dapat diselesaikan DEA adalah menentukan bobot (weight) atau timbangan untuk setiap input dan output dari suatu unit manajemen.

Dalam hal ini data yang diolah adalah data BPS Jawa Barat tahun 2015 untuk kependudukan dan ketenagakerjaan.

Dengan mengetahui efesiensi kinerja akan memudahkan instansi untuk melalukan evaluasi program kegiatan sehingga dapat dilakukan perbaikan dan peningkatan kegiatan secara khusus maupun menyeluruh.

\section{Rumusan Masalah}

Berdasarkan latar belakang masalah tersebut, maka rumusan masalah dalam penelitian ini adalah bagaimana kemampuan efesiensi instansi depnakertrans dalam mengelola penempatan kerja berdasarkan tingkat pendidikan yang di analisis dengan analisis DEA?. 


\section{Tujuan Penelitian}

Tujuan dari penelitian ini adalah untuk mengetahui efesiensi kinerja depnakertrans Jawa Barat dalam melakukan penempatan kerja berdasarkan tingkat pendidikan dengan analisis DEA (Data Envelopment Analysis).

\section{KAJIAN PUSTAKA}

\section{Data Enfelopment Analysis (DEA)}

DEA adalah sebuah teknik pemrograman matematis yang digunakan untuk mengevaluasi efisiensi relative dari suatu kumpulan unit-unit pembuat keputusan (Decision Making Unit/DMU) dalam mengelola sumber daya (input) dengan jenis yang sama sehingga menjadi hasil (output) dengan jenis yang sama pula, dimana hubungan bentuk fungsi dari input ke output diketahui. http://datariset.com/artikel/detail/data-envelopment-analysis

Data Enfelopment Analysis (DEA) adalah metode non parametric. DEA mengasumsikan bahwa tidak semua entitas adalah efesien. DEA mampu menganalysis lebih dari satu input dan /output dengan menggunakan model program linier yang menghasilkan nilai efesiensi tunggal untuk satu penelitian. (Irwandy, 2019)

DEA ini digunakan untuk mengevaluasi kinerja suatu unit yang mana dengan menggunakan analisa ini dapat diketahui unit mana dan faktor apa yang harus ditingkatkan dalam unit tersebut. Menurut Kurnia (2006), analisis DEA didesain secara spesifik untuk mengukur efisiensi relatif suatu unit produksi dalam kondisi terdapat banyak input dan banyak output, yang mana seringkali sulit untuk disiasati secara sempurna oleh teknis analisis pengukuran efisiensi lainnya. http://datariset.com/artikel/detail/data-envelopment-analysis

Secara prinsip metode DEA ini pada dasarnya merupakan teknik berbasis pemrograman linier. Beberapa software dapat digunakan untuk analisis DEA diamtaranya DS for Windows, Lindo.

\section{Pengertian Kinerja}

Bernardin dan Russel (dalam Ruky, 2002) memberikan pengertian kinerja sebagai berikut. "Performance is defined as the record of outcomes produced on a specified job function or activity during time period". Prestasi atau kinerja adalah catatan tentang hasil-hasil yang diperoleh dari fungsi-fungsi pekerjaan tertentu atau kegiatan selama kurun waktu tertentu.

Pengertian kinerja lainnya dikemukakan oleh Payaman Simanjuntak (2005) yang mengemukakan kinerja adalah tingkat pencapaian hasil atas pelaksanaan tugas tertentu

Dessler (2009) berpendapat Kinerja (prestasi kerja) karyawan adalah prestasi aktual karyawan dibandingkan dengan prestasi yang diharapkan dari karyawan. Prestasi kerja yang diharapkan adalah prestasi standar yang disusun sebagai acuan sehingga dapat melihat kinerja karyawan sesuai dengan posisinya dibandingkan dengan standar yang dibuat. Selain itu dapat juga dilihat kinerja dari karyawan tersebut terhadap karyawan lainnya.

Berdasarkan beberapa pendapat tentang kinerja dan prestasi kerja dapat disimpulkan bahwa pengertian kinerja maupun prestasi kerja mengandung substansi 
pencapaian hasil kerja oleh seseorang. Dengan demikian bahwa kinerja maupun prestasi kerja merupakan cerminan hasil yang dicapai oleh seseorang atau sekelompok orang. Kinerja perorangan (individual performance) dengan kinerja lembaga (institutional performance) atau kinrja perusahaan (corporate performance) terdapat hubungan yang erat. Dengan perkataan lain bila kinerja karyawan (individual performance) baik maka kemungkinan besar kinerja perusahaan (corporate performance) juga baik.

\section{Syarat Penilaian Kinerja}

Terdapat kurang lebih dua syarat utama yang diperlukan guna melakukan penilaian kinerja yang efektif, yaitu (1) adanya kriteria kinerja yang dapat diukur secara objektif; dan (2) adanya objektivitas dalam proses evaluasi (Gomes, 2003).

penilaian yang baik harus dilakukan secara formal berdasarkan serangkaian kriteria yang ditetapkan secara rasional serta diterapkan secara objektif serta didokumentasikan secara sistematik.

Dengan demikian, dalam melalukan penilaian atas prestasi kerja para pegawai harus terdapat interaksi positif dan kontinu antara para pejabat pimpinan dan bagian kepegawaian.

\section{Efisiensi}

Istilah efisiensi sendiri berasal dari bidang teknik, yang digunakan untuk menunjukkan rasio antara output suatu sistem terhadap input dari sistem tersebut. Pengukuran pengukuran dalam ilmu eksak tersebut selalu berpedoman pada suatu situasi ideal dimana kuantitas output yang dihasilkan sama persis dengan kuantitas input yang diberikan, atau rasio nya tepat sama dengan 1 (satu). Efisiensi dalam status ideal ini disebutdengan efisiensi ideal (absolut) yang nilainya selalu 100\%. Hal ini berarti jumlah output yang dihasilkan sama dengan jumlah input yang digunakan, sedangkan efisiensi pada keadaan tidak ideal (normal) bias lebih kecil dari $100 \%$, namun pada kenyataan nya kondisi ideal tersebut sangat sulit untuk dicapai karena banyak faktor yang mempengaruhi. (Irwandy, 2019).

\section{Pengukuran Efisiensi}

Pengukuran efesiensi dapat dilakukan dengan berbagai metode, yaitu analisis rasio, least squares regression (LSR). Total factor productifity (TFP), Data Enfelopmen Analisis (DEA). Pendekatan analisis rasio merupakan metode penilaian efisiensi yang paling sederhana karena menghasilkan informasi dari hubungan antara satu input dan satu output.

\section{METODE PENELITIAN \\ Jenis Penelitian}

Penelitian yang dilakukan adalah analisis deskriptif terhadap data kuantitatif untuk mengetahui analisis pekerjaan dan aktivitas.

Analisis kerja dan aktifitas (job and activity analysis), merupakan penelitian dengan menggunakan metode deskriptif. Penelitian ini ditujukan untuk menyelidiki secara terperinci aktivitas dan pekerjaan manusia dan hasil penelitian tersebut dapat 
memberikan rekomendasi-rekomendasi untuk keperluan masa yang akan datang (Moh Nazir, 2005).

\section{Tempat, Waktu dan Subjek Penelitian}

Penelitian ini berupa data sekunder yang diambil dari data dinas tenaga kerja dan transmigrasi oleh BPS Jawa Barat.

Tempat penelitian ini meliputi seluruh daerah Jawa Barat pada tahun 2015 yang penduduknya 46,7 juta jiwa yang terdiri atas laki-laki sebanyak 23,68 juta jiwa dan perempuan 23,03 juta jiwa.

Sasaran atau subjek penelitian ini adalah para pencari kerja yang terdaftar dan dapat ditempatkan oleh dinas Depnakertrans berdasarkan tingkat pendidikan.

\section{Teknik Pengumpulan Data}

Data yang di analisis dalam penelitian ini adalah berupa data sekunder dari Badan Pusat Statistik Jawa Barat.

\section{Teknik Analisis Data}

Data yang diperoleh akan dianalisis dengan metode Data Enfelopmen Analisis (DEA).

\section{HASIL PENELITIAN DAN PEMBAHASAN}

\section{Hasil Penelitian}

Tabel 1. Jumlah Pencari Kerja yang Terdaftar dan Dapat Ditempatkan Menurut Tingkat Pendidikan yang Ditamatkan dan Jenis Kelamin di Jawa Barat 2015

\begin{tabular}{|c|c|c|c|c|}
\hline & \multicolumn{2}{|c|}{ INPUT } & \multicolumn{2}{c|}{ OUT PUT } \\
\hline & Laki-Laki & Perempuan & Laki-Laki & Perempuan \\
\hline SD kebawah & 46.392 & $64 . .851$ & 34.177 & 41.386 \\
\hline SLTP & 59.637 & 60.124 & 32.654 & 35.478 \\
\hline SLTA & 65.282 & 76.970 & 65.421 & 68.751 \\
\hline S1 s/d S2 & 89.621 & 91.250 & 70.124 & 72.015 \\
\hline
\end{tabular}

Sumber : Data BPS, diolah (2019)

Perumusan masalah kedalam model linier programming SD ke bawah

Tujuan : Memaksimumkan total output tertimbang tingkat pendidikan SD ke bawah

\section{Variabel keputusan}

WOM SD ke bawah = Bobot output laki-laki SD ke bawah

WOW SD ke bawah = Bobot output perempuan SD ke bawah

WIM SD ke bawah = Bobot input Laki-laki SD ke bawah

WIW SD ke bawah = Bobot input perempuan SD ke bawah

\section{Jika didefenisikan}

OMj = output laki-laki ke j

OWj = output perempuan ke $\mathbf{j}$

IMj = Input laki-laki ke $\mathbf{j}$

IWj = Input perempuan ke $\mathbf{j}$ 
Fungsi Tujuan : $\mathbf{Z}$ sd = total out put tertimbang bagi tingkat pendidikan SD ke bawah Maka $: \mathrm{Z}$ sd $=$ OM sd. WOM sd + OW sd. WOW sd $: \mathrm{Z}$ sd $=34.172$. WOM sd +41.380 . WOW sd

Kendala :

1. Rasio tertimbang pada tingkat SD kebawah OM sd. WOM ${ }_{\mathrm{SD}}+\mathrm{OW}_{\mathrm{SD}}$. WOW $\mathrm{SD}-\mathrm{IM}_{\mathrm{SD}}$. WIM $\mathrm{WD}_{\mathrm{SD}}-\mathrm{IW}_{\mathrm{SD}} \cdot \mathrm{WIW}_{\mathrm{SD}} \leq 0$ 34.177. WOM $\mathrm{SD}+41.380$. WOW $\mathrm{SD}-46.392$.WIM $\mathrm{SD}-64.851$. WIW $\mathrm{SD} \leq 0$

2. Rasio tertimbang pada tingkat SLTP $\mathrm{OM}_{\text {SLTP }}$. WOM SD $+\mathrm{OW}_{\text {SLTP.WOW }}$ SD - IM $_{\text {SLTP }}$. WIM SD- IW SLTP.WIW $\mathrm{SD} \leq 0$

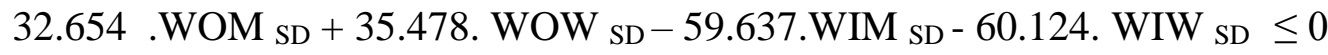

3. Rasio tertimbang pada tingkat SLTA

$\mathrm{OM}_{\text {SLTA }}$. WOM SD + OW SLTA.WOW SD - IM $_{\text {SLTA. WIM SD }}-$ IW $_{\text {SLTP }}$.WIW SD $\leq 0$ 65.421. WOM $\mathrm{SD}^{+}$68.751.WOW $\mathrm{SD}-65.282$. WIM $\mathrm{SD}_{\mathrm{SD}}-.76 .970$.WI W $\mathrm{SD} \leq 0$

4. Rasio tertimbang pada tingkat $\mathrm{S} 1 \mathrm{~s} / \mathrm{d} \mathrm{S} 2$

$\mathrm{OM}_{\mathrm{S} 1 / \mathrm{S} 2}$. WOM $\mathrm{WD}_{\mathrm{SD}}+\mathrm{OW}_{\mathrm{S} 1 / \mathrm{S} 2}$. WOW $\mathrm{SD}-\mathrm{IM}_{\mathrm{S} 1 / \mathrm{S} 2}$. WIM $\mathrm{SD}_{\mathrm{SD}}-\mathrm{IW}_{\mathrm{S} 1 / \mathrm{S} 2} \cdot \mathrm{WIW}_{\mathrm{SD}} \leq 0$

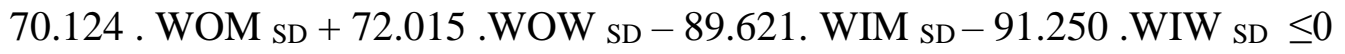

5. Input pada tingkat SD ke bawah $\mathrm{IM}_{\mathrm{SD}}$. WIM SD + IW SD . WIW $\mathrm{SD}=1$ 46.392. WIM $\mathrm{SD}+64.851$. WIW $\mathrm{SD}=1$

6. Non Negatif : WOM ${ }_{\mathrm{SD}}$; WOW $\mathrm{SD}$; WIM ${ }_{\mathrm{SD}}$ dan WIW $\mathrm{SD} \geq 0$

Formulasi Model Programing (Untuk data entri komputer)

1. Fungsi tujuan: Maksimumkan $\mathrm{Z}_{\mathrm{A}}=34.177$. WOM $\mathrm{SD}+41.380$ WOW $\mathrm{SD}$

2. Kendala:

SD kebawah :34.177.WOM $_{\text {SD }}+$ 41.380. WOW $_{\text {SD }}$ - 46.392.WIM SD $_{\text {- 64.851.WIW }}$ $\mathrm{SD} \leq 0$

SLTP : 32.654. WOM SD + 35.478. WOW SD $_{\text {S }}$ 59.637.WIM SD 60.124.WIW $\mathrm{SD} \leq 0$ SLTA $: 65.421 . \mathrm{WOM}_{\mathrm{SD}}+68.751 . \mathrm{WOW}_{\mathrm{SD}}-65.282$. $\mathrm{WIM}_{\mathrm{SD}}-76.970 . \mathrm{WIW}_{\mathrm{SD}} \leq 0 \quad \mathrm{~S} 1 / \mathrm{S} 2 \quad: 70.124 . \mathrm{WOM}_{\mathrm{SD}}+72.015 . \mathrm{WOW}$ $\mathrm{SD}-89.621$. WIM ${ }_{\mathrm{s}} 91.250$.WIW $\mathrm{SD} \leq 0$

3. Input tingkat SD kebawah : 46.392.WIM SD +64.851 . WIW $\mathrm{SD}=1$

4. Non Negatif: WOM ${ }_{\mathrm{SD}}$;WOW $\mathrm{SD} ; \mathrm{WIM}_{\mathrm{SD}}$ dan WIW $\mathrm{SD} \geq 0$ 
Analisis efesiensi pada tingkat pendidikan SD kebawah dengan menggunakan DEA

Tabel 2. Data Input Komputer Tingkat Pendidikan SD ke bawah

\begin{tabular}{|l|r|r|r|r|r|r|}
\hline & & \multicolumn{5}{|c|}{ KINERJA DEFNAKERTRANS } \\
\hline & WOM SD & WOW SD & WIM SD & WIW SD & RHS \\
\hline Maximize & 34,177 & 41,386 & 0 & 0 & 0 \\
\hline SD ke bawah & 34,177 & 41,386 & $-46,392$ & $64,851<=$ & 0 \\
\hline SLTP & 32,654 & 35,478 & $-59,637$ & $-60,124<=$ & 0 \\
\hline SLTA & 65,421 & 68,751 & $-65,282$ & $76,970<=$ & 0 \\
\hline S1/S2 & 70,124 & 72,015 & $-89,621$ & $91,250<=$ & 0 \\
\hline Input SD ke bawah & 0 & 0 & 46,392 & $64,851<=$ & $<$ \\
\hline
\end{tabular}

Sumber : Hasil Penelitian, diolah (2019)

Tabel 3. Hasil Output Tingkat Pendidikan SD ke bawah

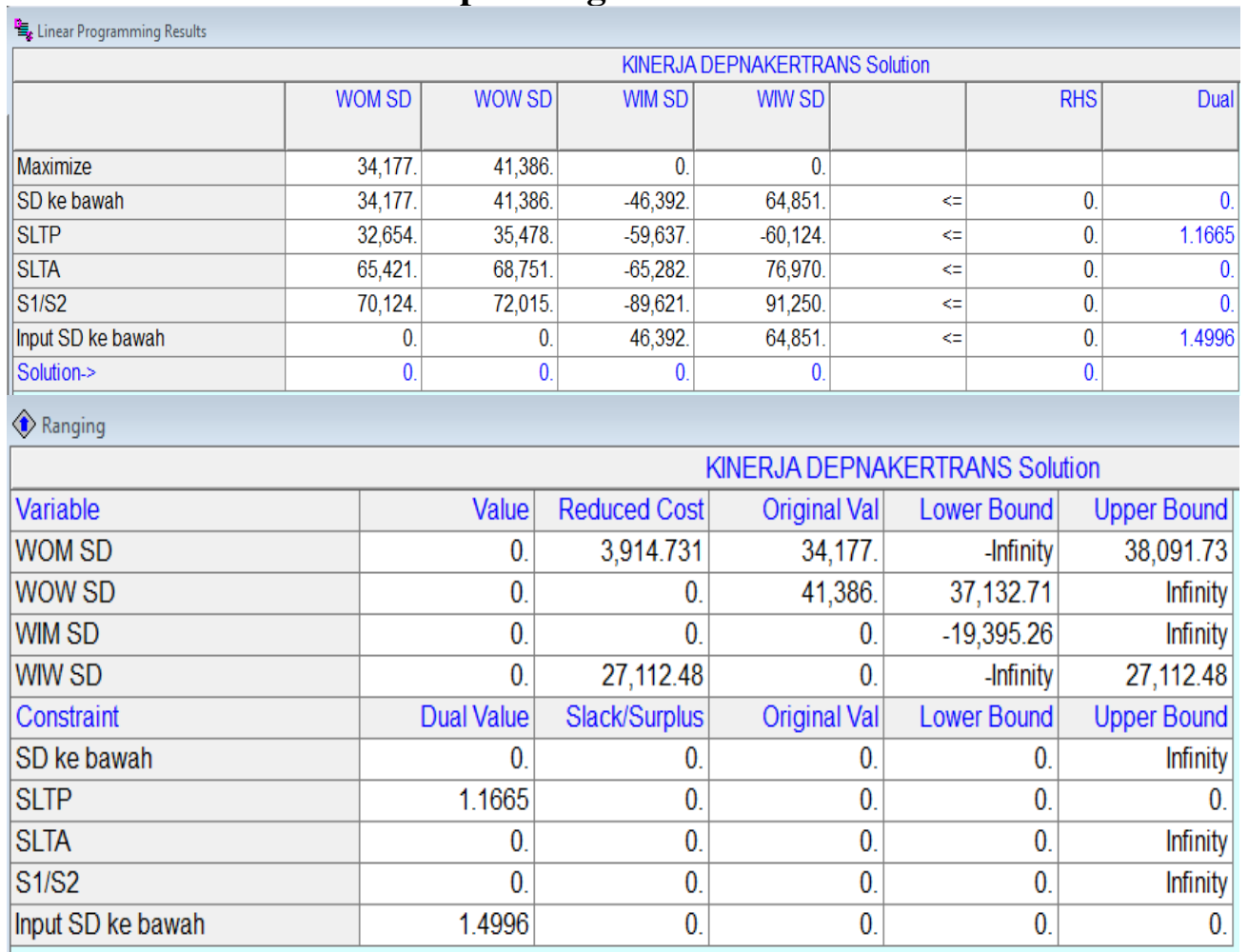

Sumber : Hasil Penelitian, diolah (2019)

\section{Telaah hasil RUN komputer tingkat pendidikan SD ke bawah}

Dari output computer nampak bahwa hasil kinerja depnakertran Jawa Barat dalam penempatan kerja tidak efisien karrena nilai fungsi tujuannya (objective function value) sama dengan nol (0).

Nilai fungsi tujuan itu juga sama dengan shadow price (nilai dual) pada kendala ekstra (total input tertimbang SD kebawah, yaitu nol (0) . 


\title{
Perumusan masalah kedalam model linier programming tingkat SLTP
}

Tujuan : Memaksimumkan total output tertimbang tingkat pendidikan SLTP

\author{
Variabel keputusan \\ WOM SLTP = Bobot out put laki-laki SLTP \\ WOW SLTP = Bobot out put perempuan SLTP \\ WIM SLTP $=$ Bobot input Laki-laki SLTP \\ WIW SLTP $=$ Bobot input perempuan SLTP
}

\section{Jika didefenisikan}

OMj = out put laki-laki ke $\mathbf{j}$

OWj = out put perempuan ke $\mathbf{j}$

IMj = Input laki-laki ke $\mathbf{j}$

IWj = Input perempuan ke $\mathbf{j}$

Fungsi Tujuan : $\mathbf{Z}_{\text {SLTP }}=$ total out put tertimbang bagi tingkat pendidikan SLTP

Maka $\quad: Z_{\text {SLTP }}=$ OM $_{\text {SLTP }}$. WOM SLTP + OW $_{\text {SLTP }}$. WOW SLTP

$$
: Z_{\text {SLTP }}=32.654 . \mathrm{WOM}_{\text {SLTP }}+35.478 . \mathrm{WOW}_{\text {SLTP }}
$$

Kendala :

1. Rasio tertimbang pada tingkat SD kebawah

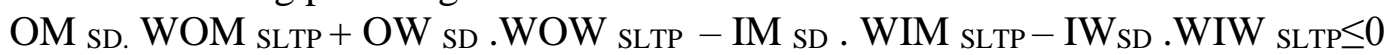

34.177. WOM SLTP $^{+}$41.380. WOW SLTP -46.392 .WIM SLTP -64.851 . WIW SLTP $\leq 0$

2. Rasio tertimbang pada tingkat SLTP

OM SLTP . WOM SLTP + OW SLTP.WOW SLTP - IM SLTP . WIM SLTP - IW .WIW SLTP $\leq 0$

32.654. WOM $_{\text {SLTP }}+35.478$. WOW $_{\text {SLTP }}-59.637$. WIM $_{\text {SLTP- }}$ 60.124. WIW SLTP $\leq 0$

3. Rasio tertimbang pada tingkat SLTA

OM $_{\text {SLTA }} . W_{\text {SLTP }}+$ OW $_{\text {SLTA. WOW }}$ SLTP - IM SLTA. WIM SLTP . IW SLTA. WIW SLTP $\leq$

65.421. WOM SLTP + 68.751. WOW SLTP -65.282. WIM $_{\text {SLTP }}-$.76.970.WI W SLTP $\leq$ 0

4. Rasio tertimbang pada tingkat $\mathrm{S} 1 \mathrm{~s} / \mathrm{d} \mathrm{S} 2$

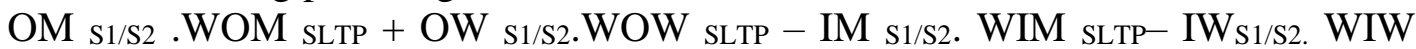
SLTP $\leq 0$

70.124. WOM SLTP +72.015. WOW SLTP -89.621. WIM SLTP $^{-9}$ - 1.250 .WIW SLTP $\leq 0$

5. Input pada tingkat SLTP

IM $_{\text {SLTP }}$. WIM SLTP + IW SLTP. WIW SLTP $=1$

46.392. WIM SLTP +64.851 . WIW SLTP $=1$ 


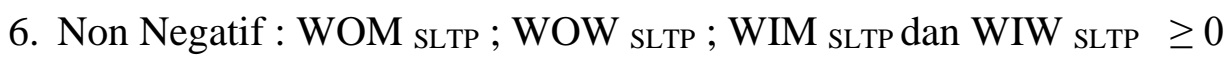

\section{Analisis efesiensi pada tingkat pendidikan SLTP kebawah dengan menggunakan DEA}

Tabel 4. Data Input Komputer Tingkat Pendidikan SLTP

\begin{tabular}{|c|c|c|c|c|c|c|}
\hline \multicolumn{7}{|c|}{ KINERJA DEPNAKERTRANS } \\
\hline & & & & & & \\
\hline & WOM SLTP & WOW SLTP & WIM SLTP & WIW SLTP & & RHS \\
\hline Maximize & 32,654 & 35,478 & 0. & 0 & & \\
\hline SD ke bawah & 34,177 & 41,386 & $-46,392$. & 64,851 & $<=$ & 0 \\
\hline SLTP & 32,654 & 35,478 & $-59,637$. & $-60,124$ & $4<=$ & 0 \\
\hline SLTA & 65,421 & 68,751 & $-65,282$ & 76,970 & $<=$ & 0 \\
\hline S1/S2 & 70,124 & 72,015 & $-89,621$ & 91,250 & $<=$ & 0 \\
\hline Input SLTP & 0 & 0 & 59.637 & 60,124 & $t \leqslant \nabla$ & 0 \\
\hline
\end{tabular}

Sumber : Hasil Penelitian, diolah (2019)

Tabel 5. Hasil Output Tingkat Pendidikan SLTP

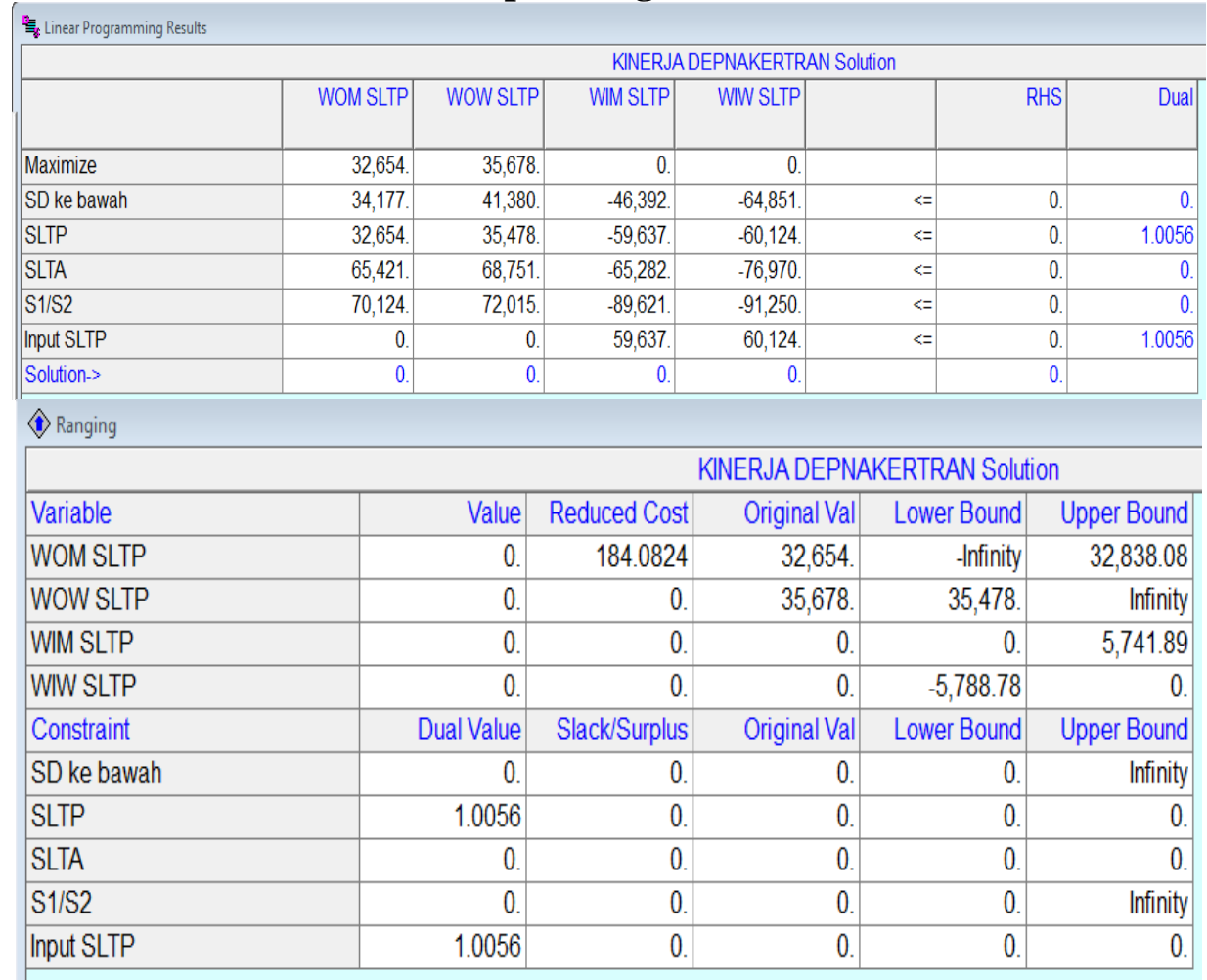

Sumber : Hasil Penelitian, diolah (2019)

\section{Telaah hasil RUN komputer tingkat pendidikan SLTP}

Dari output komputer nampak bahwa hasil kinerja depnakertran Jawa Barat dalam penempatan kerja untuk tingkat SLTP efektif karena dari nilai fungsi tujuannya (objective function value) $=1,0056$. Nilai fungsi tujuan tersebut juga sama dengan shadow price (nilai dual) pada kendala ekstra (total input tertimbang tingkat SLTP) Hal ini mengidentifikasikan bahwa depnakertran Jawa Barat mampu menempatkan 
tenaga kerja tingkat SLTP secara optimal dengan input yang ada.Penempatan tingkat SLTP efesien, hal ini juga ditunjukkan oleh shadow price atau nilai dual dari tingkat pendidikan SLTP yang tidak bernilai nol $(=1,0056)$.

\section{Perumusan masalah kedalam model linier programming tingkat SLTA}

Tujuan : Memaksimumkan total output tertimbang tingkat pendidikan SLTA

Variabel keputusan

WOM SLTP = Bobot out put laki-laki SLTA

WOW SLTP = Bobot out put perempuan SLTA

WIM SLTP = Bobot input Laki-laki SLTA

WIW SLTP = Bobot input perempuan SLTA

\section{Jika didefenisikan}

OMj = out put laki-laki ke $\mathrm{j}$

OWj = out put perempuan ke $\mathbf{j}$

IMj = Input laki-laki ke $\mathbf{j}$

IWj = Input perempuan ke $\mathbf{j}$

Fungsi Tujuan : $\mathbf{Z}_{\text {SLTA }}=$ total out put tertimbang bagi tingkat pendidikan SLTA

Maka

$$
\begin{aligned}
& : Z_{\text {SLTA }}=\text { OM }_{\text {SLTA }} . \text { WOM }_{\text {SLTA }}+\text { OW }_{\text {SLTP }} . \text { WOW } \text { SLTA } \\
& : Z_{\text {SLTA }}=65.421 . \text { WOM }_{\text {SLTA }}+68.751 . \text { WOW } \text { SLTA }
\end{aligned}
$$

Kendala :

1. Rasio tertimbang pada tingkat SD kebawah

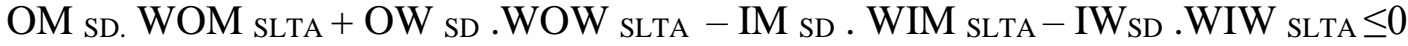

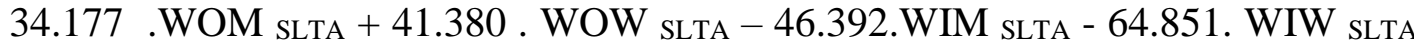
$\leq 0$

2. Rasio tertimbang pada tingkat SLTP

$\mathrm{OM}_{\text {SLTP }}$.WOM SLTA $+\mathrm{OW}_{\text {SLTP. WOW }}$ SLTA $_{-}$IM $_{\text {SLTP. }}$ WIM $_{\text {SLTA }}$ IW $_{\text {SLTP }}$.WIW SLTA $\leq 0$

32.654.WOM SLTA +35.478 . WOW SLTA -59.637. WIM $_{\text {SLTA }}-60.124$ WIW $_{\text {SLTA }} \leq$ 0

3. Rasio tertimbang pada tingkat SLTA

$\mathrm{OM}_{\text {SLTA }}$.WOM SLTA + OW SLTA.WOW SLTA- IM SLTA. WIM SLTA - IW SLTA .WIW SLTA $\leq 0$

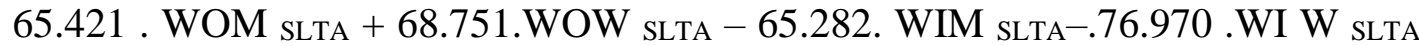
$\leq 0$

4. Rasio tertimbang pada tingkat $\mathrm{S} 1 \mathrm{~s} / \mathrm{d} \mathrm{S} 2$

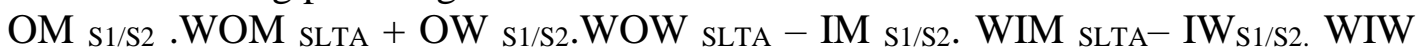
SLTA $\leq 0$

70.124. WOM ${ }_{\text {SLTA }}+72.015$. WOW $_{\text {SLTA }}-89.621$ WIM $_{\text {SLTA }}-91.250$.WIW SLTA $\leq 0$ 
5. Input pada tingkat SLTA

IM $_{\text {SLTA }}$. WIM SLTPA $_{\text {IW }}$ SLTA. WIW SLTA $=1$

65.282. WIM SLTA $^{+76.970 . ~}$ WIW $_{\text {SLTA }}=1$

6. Non Negatif : WOM SLTA ; WOW SLTA; WIM SLTA dan WIW SLTA $\geq 0$

Analisis efesiensi pada tingkat pendidikan SLTA dengan menggunakan DEA

Tabel 6. Data Input Komputer Tingkat Pendidikan SLTA

\begin{tabular}{|l|r|r|r|r|r|r|}
\hline & & & \multicolumn{5}{|c|}{ KINERJA DEPNAKERTRAN } \\
\hline & WOM SLTA & WOW SLTA & WIM SLTA & WIW SLTA & RHS \\
\hline Maximize & 65,421 & 68,751 & 0 & 0 & \\
\hline SD ke bawah & 34,177 & 41,380 & $-46,392$ & $-64,851<=$ & 0 \\
\hline SLTP & 32,654 & 35,478 & $-59,637$ & $-60,124<=$ & 0 \\
\hline SLTA & 65,421 & 68,751 & $-65,282$ & $-76,970<=$ & 0 \\
\hline S1/S2 & 70,124 & 72,015 & $-89,621$ & $-91,250<=$ & 0 \\
\hline Input SLTA & 0 & 0 & 65,282 & $76,970<=$ & 0 \\
\hline
\end{tabular}

Sumber : Hasil Penelitian, diolah (2019)

Tabel 7. Hasil Output Tingkat Pendidikan SLTA

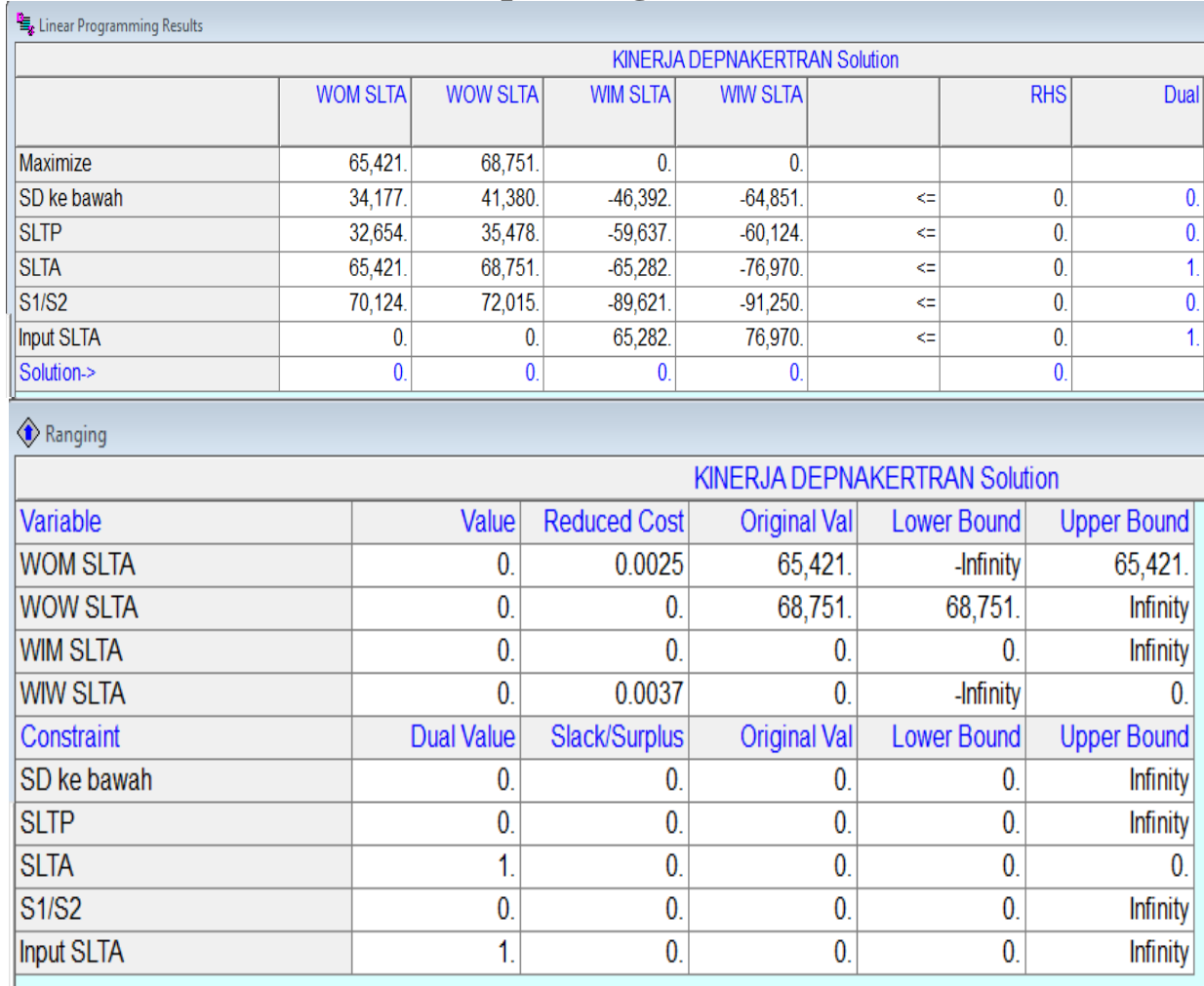

Sumber : Hasil Penelitian, diolah (2019)

Rosmita $^{1)}$, Ety Nurhayaty ${ }^{2)}$, Dini Setyorini ${ }^{3)}$ 


\section{Telaah hasil RUN komputer tingkat Pendidikan SLTA}

Dari output computer nampak bahwa hasil kinerja depnakertran Jawa Barat dalam penempatan kerja untuk tingkat SLTA efektif karena dari nilai fungsi tujuannya (objective function value $)=1$...Nilai fungsi tujuan tersebut juga sama dengan shadow price (nilai dual) pada kendala ekstra (total input tertimbang tingkat SLTA) Hal ini mengidentifikasikan bahwa depnakertran Jawa Barat mampu menempatkan tenaga kerja tingkat SLTA secara optimal dengan input yang ada.Penempatan tingkat SLTA efesien, hal ini juga ditunjukkan oleh shadow price atau nilai dual dari tingkat pendidikan SLTA yang tidak bernilai nol (=1)

Perumusan masalah kedalam model linier programming tingkat S1/S2

Tujuan : Memaksimumkan total output tertimbang tingkat pendidikan S1/S2

Variabel keputusan

WOM S1/S2 = Bobot out put laki-laki S1/S2

WOW S1/S2 = Bobot out put perempuan S1/S2

WIM S1/S2 = Bobot input Laki-laki S1/S2

WIW S1/S2 = Bobot input perempuan S1/S2

\section{Jika didefenisikan}

OMj = out put laki-laki ke $\mathrm{j}$

OWj = out put perempuan ke $\mathbf{j}$

IMj = Input laki-laki ke $\mathbf{j}$

IWj = Input perempuan ke $\mathbf{j}$

Fungsi Tujuan : $\mathbf{Z}$ S1/S2 = total out put tertimbang bagi tingkat pendidikan S1/S2

Maka $\quad: Z_{\mathrm{S} 1 / \mathrm{s} 2}=\mathrm{OM}_{\mathrm{S} 1 / \mathrm{S} 2}$. WOM s1/s2+ OW s1/s2. WOW s1/S2

Kendala :

$$
: \mathrm{Z}_{\mathrm{S} 1 / \mathrm{S} 2}=70.124 . \mathrm{WOM}_{\mathrm{S} 1 / \mathrm{S} 2}+72.015 . \mathrm{WOW}_{\mathrm{S} 1 / \mathrm{S} 2}
$$

1. Rasio tertimbang pada tingkat SD kebawah

$\mathrm{OM}_{\mathrm{SD}}$. $\mathrm{WOM}_{\mathrm{S} 1 / \mathrm{S} 2}+\mathrm{OW}_{\mathrm{SD}} \cdot \mathrm{WOW}_{\mathrm{S} 1 / \mathrm{S} 2}-\mathrm{IM}_{\mathrm{SD}} \cdot \mathrm{WIM}_{\mathrm{S} 1 / \mathrm{S} 2}-\mathrm{IW}_{\mathrm{SD}} \cdot \mathrm{WIW}_{\mathrm{S} 1 / \mathrm{S} 2} \leq 0$

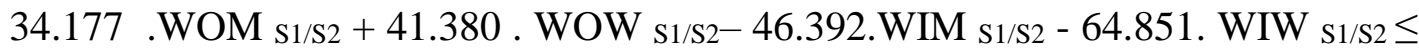
0

2. Rasio tertimbang pada tingkat SLTP

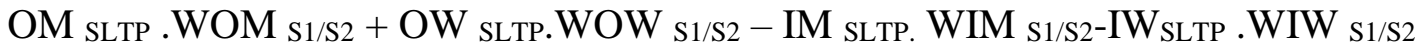
$\leq 0$

32.654.WOM S1/S2 +35.478 WOW $_{\mathrm{S} 1 / \mathrm{S} 2}-59.637 . \mathrm{WIM}_{\mathrm{S} 1 / \mathrm{S} 2}-60.124$ WIW $_{\mathrm{S} 1 / \mathrm{S} 2} \leq$ 0

3. Rasio tertimbang pada tingkat SLTA

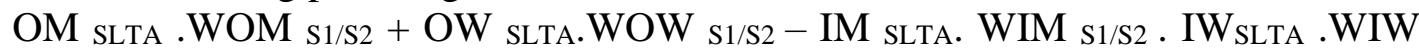
$\mathrm{S} 1 / \mathrm{S} 2 \leq$

65.421. WOM $_{\mathrm{s} 1 / \mathrm{s} 2}+68.751 . \mathrm{WOW}_{\mathrm{s} 1 / \mathrm{s} 2}-65.282$ WIM $_{\mathrm{S} 1 / \mathrm{s} 2-}-76.970 . \mathrm{WI}_{\mathrm{S} 1 / \mathrm{S} 2}$ $\leq 0$

4. Rasio tertimbang pada tingkat $\mathrm{S} 1 \mathrm{~s} / \mathrm{d} \mathrm{S} 2$

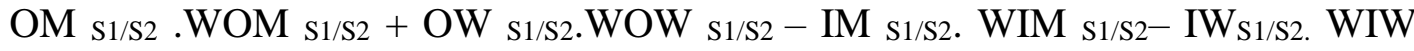
$\mathrm{S} 1 / \mathrm{S} 2 \leq 0$ 
70.124. WOM $_{\mathrm{s} 1 / \mathrm{s} 2}+72.015 . \mathrm{WOW}_{\mathrm{s} 1 / \mathrm{S} 2}-89.621$. WIM $_{\mathrm{S} 1 / \mathrm{s} 2}-91.250 . \mathrm{WIW}_{\mathrm{s} 1 / \mathrm{s} 2} \leq$ 0

5. Input pada tingkat $\mathrm{S} 1 / \mathrm{S} 2$

$\mathrm{IM}_{\mathrm{S} 1 / \mathrm{S} 2}$. WIM s1/s2 + IW $\mathrm{s} 1 / \mathrm{S} 2$. WIW $\mathrm{s} 1 / \mathrm{S} 2=1$

89.621.WIM S1/s2+ 92.250. WIW s1/S2 $=1$

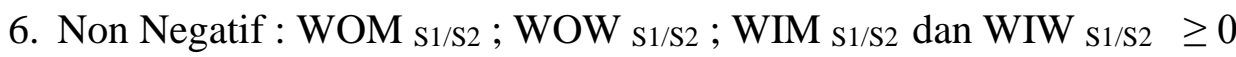

\section{Analisis efesiensi pada tingkat pendidikan S1/S2 dengan menggunakan DEA}

Tabel 8. Data Input Komputer Tingkat Pendidikan S1 / S2

\begin{tabular}{|l|r|r|r|r|r|r|}
\hline & & \multicolumn{5}{|c|}{ KINERJA DEPNAKERTRAN } \\
\hline & WOM S1/S2 & WOW S1/S2 & WIM S1/S2 & WIW S1/S2 & RHS \\
\hline Maximize & 70,124 & 72,015 & 0 & 0 & \\
\hline SD ke bawah & 34,177 & 41,380 & $-46,392$ & $-64,851<=$ & 0 \\
\hline SLTP & 32,654 & 35,478 & $-59,637$ & $-60,124<=$ & 0 \\
\hline SLTA & 65,421 & 68,751 & $-65,282$ & $-76,970<=$ & 0 \\
\hline S1/S2 & 70,124 & 72,015 & $-89,621$ & $-91,250<=$ & 0 \\
\hline Input S1/S2 & 0 & 0 & 89,621 & $92,250<=$ & 0 \\
\hline
\end{tabular}

Sumber : Hasil Penelitian, diolah (2019)

Tabel 9. Hasil Output Tingkat Pendidikan S1/S2

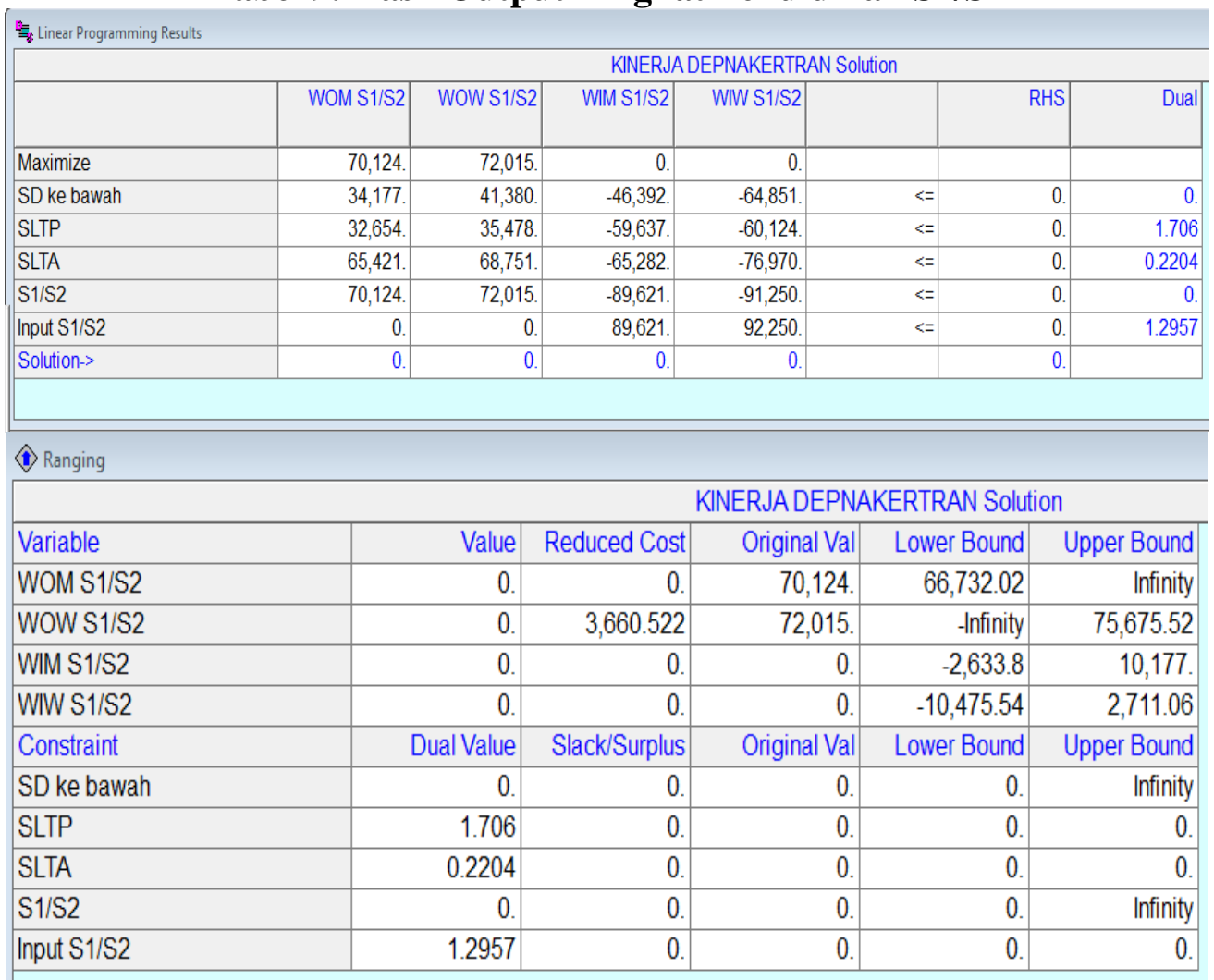

Sumber : Hasil Penelitian, diolah (2019)

Rosmita $^{1)}$, Ety Nurhayaty ${ }^{2)}$, Dini Setyorini ${ }^{3)}$ 


\section{Telaah hasil RUN komputer tingkat pendidikan S1/S2}

Dari output komputer nampak bahwa hasil kinerja depnakertran Jawa Barat dalam penempatan kerja untuk tingkat $\mathrm{S} 1 / \mathrm{S} 2$ efektif karena dari nilai fungsi tujuannya (objective function value) $=1.2957$..Nilai fungsi tujuan tersebut juga sama dengan shadow price (nilai dual) pada kendala ekstra (total input tertimbang tingkat S1/S2) Hal ini mengidentifikasikan bahwa depnakertran Jawa Barat mampu menempatkan tenaga kerja tingkat S1/S2 secara optimal dengan input yang ada.Penempatan tingkat S1/S2 efesien, hal ini juga ditunjukkan oleh shadow price atau nilai dual dari tingkat pendidikan SLTP yang tidak bernilai nol (1.2957)

\section{KESIMPULAN DAN SARAN \\ Kesimpulan}

Berdasarkan pembahasan tersebut maka dapat disimpulkan bahwa secara umum kinerja depnakertrans Jawa Barat cukup efisien ,hanya kinerja dalam penempatan tingkat SD ke bawah yang tidak efisien sedangkan untuk tingkat pendidikan SLTP,SLTA dan S1/S2 efisien.

\section{Saran}

1. Untuk meningkatkan efesiensi kinerja karyawan depnakertrans Jawa Barat, beberapa kebijakan dan terobosan perlu dilakukan para pimpinan dan penanggung jawab terhadap karyawan dalam peningkatan keahlian atau skil karyawan dalam penanganan kasus di masyarakat.

2. Para Pimpinan Depnakertrans dan yang terkait diharapkan dapat memberikan kontribusi dan solusi kepada masyarakat khusus nya untuk tamatan Sd kebawah dalam peningkatan sumber daya sehingga siap bersaing dalam dunia kerja.

\section{DAFTAR PUSTAKA}

Dessler, Gary. 2009. Manajemen SDM buku I. Jakarta: Indeks.

Gomes, Faustino Cardosa, Dr. 2003. MSDM. Yogyakarta. Andi

Irwandy. 2019. Efisiensi dan Produktifitas Rumah Sakit Teori dan Aplikasi Pengukuran dengan Pendekatan Data Envelopment Analysis, Cetakan pertama, CV Social Politic Genius. (SIGn), Makasar

Nazir, Moh. 2005. Metode Penelitian. Bogor: Ghalia Indonesia.

Ruky, Ahmad. 2002. Sistem Manajemen Kinerja. Jakarta: Gramedia Pustaka Utama

Simanjuntak, Payaman J. 2005. Manajemen dan Evaluasi Kerja. Jakarta: Lembaga Penerbit FEUI

http://datariset.com/artikel/detail/data-envelopment-analysis

https://jabar.bps.go.id 